\title{
Hubungan Agama dan Negara di Indonesia: Polemik dan Implikasinya dalam Pembentukan dan Perubahan Konstitusi
}

\author{
Ahmad Sadzali \\ Fakultas Hukum Universitas Islam Indonesia \\ sadzali@uii.ac.id
}

\begin{abstract}
For ages, the relationship between state and religion in Indonesia is always become a controversy, and the tension were getting higher in the early period before the declaration of independence. This article discusses how the controversy was occurred within period of Constitution making, and its influence in the text of Constitution, amendment or replacement of the Constitution. The debate on the issue of state and religion were focused on weather Indonesia would become a religious state (Islamic state) or secular state. The issue was consciously repeated in the event of amendment or replacement of Constitution. The implication of the discourse between state and religion lead to the gentlemen agreement on Pancasila, which one of the principles is "Believe in one God". Therefore, the principle is reflected in Constitution such as recognition of certain religions; equality among the officially recognized religions; guaranteeing of freedom of religion; human rights protection which consider religious values; and developing national education system that based on religious aspect.
\end{abstract}

Keywords: religion; state; Pancasila; Constitution. 


\section{Abstrak}

Polemik tentang hubungan antara agama dan negara di Indonesia sesungguhnya telah berlangsung lama, dan semakin meningkat tensinya pada saat kemerdekaan Indonesia sedang dipersiapkan. Artikel ini membahas bagaimana polemik itu berlangsung dalam kaitannya dengan pembentukan dan perubahan Konstitusi, dan bagaimana pula implikasinya pada Konstitusi yang dibentuk, diganti, dan diamandemen. Dalam artikel ini ditunjukkan, polemik hubungan agama dan negara berlangsung sengit pada masa persiapan kemerdekaan, atau jika dikaitkan dengan Konstitusi berarti pada saat Konstitusi pertama sedang dirumuskan. Polemik itu berkutat pada perdebatan apakah Indonesia menjadi negara agama (Islam) ataukah negara yang tidak didasarkan pada agama tertentu. Polemik semacam ini ternyata kembali berulang pada saat Konstitusi diganti dan diamandemen. Pada perkembangannya, polemik ini berimplikasi pada lahirnya kesepakatan mulia berupa Pancasila, di mana negara didasarkan salah satunya pada "Ketuhanan Yang Maha Esa". Dalam isi atau batang tubuh Konstitusi, kesepakatan semacam ini menimbulkan implikasi turunannya berupa pengakuan negara terhadap eksistensi agama tertentu; perlakuan secara sama terhadap semua agama yang diakui; pemberian jaminan kebebasan penduduk untuk memeluk dan menjalankan ajaran agama; pengakuan dan penghormatan hak asasi yang mempertimbangkan nilai-nilai agama; dan pengembangan pendidikan nasional yang berbasis dan berorientasi pada peningkatan aspek spiritual keagamaan.

Kata Kunci: agama; negara; Pancasila; Konstitusi.

\section{A. Pendahuluan}

Artikel ini membahas hubungan antara agama dan negara di Indonesia dalam kaitannya dengan pembentukan dan perubahan Konstitusi. Pertanyaan yang ingin didiskusikan adalah bagaimanakah polemik hubungan agama dan negara berlangsung dalam pembentukan dan perubahan Konstitusi, serta apa pula implikasinya dalam pembentukan dan perubahan Konstitusi. Di Indonesia sendiri, Konstitusi yang pernah dan yang disebut terakhir merupakan yang berlaku saat ini, adalah Undang-Undang Dasar Republik Indonesia 1945, Konstitusi Republik Indonesia Serikat (RIS), Undang-Undang Dasar Sementara 
1950, dan Undang-Undang Dasar Negara Republik Indonesia Tahun 1945.

Pembahasan persoalan hubungan agama dan negara ini, sekalipun merupakan tema klasik untuk konteks Indonesia, tetap penting dan relevan setidaknya karena tiga alasan. Pertama, secara historis, masyarakat yang mendiami wilayah yang pasca kolonial disebut Indonesia sesungguhnya sangat lekat dengan agama, keagamaan atau sistem kepercayaan tertentu. Sebelum masuk agama Hindu maupun Buddha, ${ }^{1}$ masyarakat Nusantara menganut kepercayaan tertentu. ${ }^{2}$ Setelah Islam datang, semakin memperkuat rasa kebatinan masyarakat Indonesia terhadap ajaran ketuhanan. ${ }^{3}$ Sehingga menjadi tidak berlebihan jika dikatakan salah satu karakter masyarakat

1 Riwayat agama-agama di Nusantara dapat ditelusuri melalui peradaban yang mendapatkan pengaruh agama-agama, antara lain prasasti-prasasti Raja Mulawarman dari Kutei yang ditemukan pada abad ke 4 Masehi dan Raja Purnawarman dari Tarumanegara pada pertengahan abad ke 5. Meskipun dalam berbagai prasasti yang ditemukan itu terdapat anasir agama Weda, kedua Raja tersebut umumnya dianggap sebagai penganut agama Hindu. Sedangkan berdasarkan sumber tertulis, kedatangan agama Hindu di Nusantara terlihat pada prasasti Tuk Mas di Desa Lebak, Magelang, pada pertengahan abad ke 7 . Pada waktu yang bersamaan, abad ke 7, juga ditemukan peradaban agama Buddha melalui prasasti kerajaan Sriwijaya. Titi Surti Nastiti, "Jejak-jejak Peradaban Hindu-Buddha di Nusantara”, Kalpataru: Majalah Arkeologi, 23, 1 (2014), hlm. 35-36.

2 Pada umumnya, kepercayaan-kepercayaan lokal yang muncul sebelum agama Hindu dikenali sebagai Animisme dan Dinamisme. Sebutan ini, sebagaimana dikatakan Ronald Adam, sesungguhnya bermasalah, dikarenakan animisme itu sesungguhnya konstruksi di Barat abad 19, khususnya dalam kajian antropologi, yang kemudian dibawa ke Timur seiring kolonialisme. Di Nusantara, konsep ini diperkenalkan pada 1906 oleh sarjana Belanda Albert Kruyt. Ronald Adam, "Asal Mula Teori Animisme dan Masalahnya", https: / / crcs.ugm.ac.id/asal-mula-teori-animisme-dan-masalahnya/, $18 / 9 / 2019$, diakses $10 / 11 / 2020$.

3 Interaksi masyarakat Nusantara dengan Islam, yang mengawali kedatangan dan perkembangan Islam di Nusantara, tercatat sudah berlangsung sejak abad pertama Hijriah atau abad 7-8 Masehi. Islam kemudian diterima secara luas oleh masyarakat Nusantara melalui dua pola: diterima terlebih dahulu oleh masyarakat lapisan bawah, kemudian berkembang dan diterima oleh masyarakat lapisan atas atau elite kerajaan. Pola islamisasi yang disebut terakhir terlihat mendominasi di kawasan Melayu-Nusantara melalui naskah sejarah melayu. Aziz, "Islamisasi Nusantara Perspektif Naskah Sejarah Melayu”, Thaqafiyyat, 16, 1 (2015), hlm. 60, 63, 73. 
Indonesia adalah masyarakat yang religius.

Kedua, secara filosofis dan dasar kenegaraan, Indonesia mengakui dan menjadikan agama sebagai bagian dari prinsip-prinsip dalam berbangsa dan bernegara. Dalam dasar negara Pancasila, sila pertama "Ketuhanan yang Maha Esa" menunjukkan Indonesia mengakui tentang kehidupan berbangsa dan bernegara yang didasarkan pada Ketuhanan, atau dalam konteks artikel ini disebut agama. Pada umumnya, dalam soal hubungan agama dan negara, negara akan bersikap tegas dengan mendasarkan pada agama tertentu (biasa disebut negara agama) atau malah sebaliknya tidak dikait-kaitkan dengan agama (disebut negara sekuler). Sementara Indonesia tidak mengakui agama tertentu sebagai agama resmi negara, secara bersamaan mengakui adanya keberadaan sekaligus mendukung berkembangnya sejumlah agama, yaitu Islam, Protestan, Katolik, Hindu, Budha, dan Kongkhucu. Dengan demikian Indonesia bukanlah negara agama dan sekaligus juga bukan negara sekuler. Tipologi bernegara semacam ini oleh Jeremy Menchik disebut negara dengan nasionalisme bertuhan (godly nationalism), ${ }^{4}$ atau dalam uraian nanti disebut dengan konsep negara tamyiz. ${ }^{5}$

Ketiga, pasca kolonialisme, persoalan agama dan negara masih kerap mewarnai dan bahkan menjadi persolan serius dalam kehidupan sosial politik di Indonesia. Polemik agama dan negara kerap kali muncul dalam kontestasi politik, yang memperlihatkan upaya politisasi. Jika polemik ini terus dipelihara hanya untuk kepentingan politik praktis sektoral, tidak menutup kemungkinan akan terjadi polarisasi berkepanjangan di tengah masyarakat, yang berujung pada disintegrasi bangsa. Terlebih kelompok ekstrem kiri dan ekstrem kanan dapat dirasakan kehadiran ancamannya yang mencoba mengulang kembali polemik tersebut. ${ }^{6}$ Bahkan tidak hanya

4 R. William Liddle, "Tantangan Nasionalisme Bertuhan”, harian Kompas, 20/09/2014.

5 Ahmad Sadzali, Relasi Agama dan Negara: Teokrasi-Sekular-Tamyiz (Yogyakarta: Pusat Studi Hukum Islam Fakultas Hukum UII, 2018), hlm. 45. Konsep negara tamyiz ini secara ringkas nanti dijelaskan pada bagian Diskursus Relasi Agama dan Negara.

6 Anas Saidi, "Relasi Pancasila, Agama dan Kebudayaan: Sebuah Refleksi", 
dalam ranah politik, persoalan relasi agama dan negara juga berlanjut pada medan lain seperti ekonomi, pendidikan, hukum, kebudayaan dan lainnya.

Oleh karena itu, sekalipun klasik, persoalan hubungan antara agama dan negara di Indonesia yang begitu dinamis menjadi tetap relevan untuk dikaji. Idealnya, polemik relasional tersebut sudah selesai ketika ditetapkannya Undang-Undang Dasar Tahun 1945. Kesepakatan dasar negara dalam Konstitusi semestinya dihormati dan dijalankan oleh semua elemen bangsa.

Dalam artikel ini, pembahasan relasi agama dan negara dibatasi dalam kaitannya dengan pembentukan dan perubahan Konstitusi. Dalam membahasnya, artikel ini setelah ini menguraikan terlebih dahulu diskursus relasi agama dan negara, dengan tujuan untuk menunjukkan bagaimana polemik agama dan negara ini secara teoretis muncul. Bagian berikutnya memaparkan hubungan agama dan negara pada masa kolonialisme, dan dilanjutkan dengan polemiknya dalam perumusan Konstitusi UUD 1945. Bagian sesudahnya membahas polemik relasional tersebut dalam perubahan Konstitusi: Konstitusi RIS, UUDS 1950, dan UUD NRI Tahun 1945. Setelahnya, bahasan dilanjutkan dengan identifikasi implikasi polemik tersebut pada pembentukan dan perubahan Konstitusi. Artikel diakhiri dengan penyampaian kesimpulan.

\section{B. Diskursus Relasi Agama dan Negara}

Secara teoritis, banyak usulan tipologi mengenai relasi agama dan negara yang muncul dan berkembang. Tipologi yang paling klasik tentu adalah negara teokrasi, yaitu menyatunya agama dan negara, dan negara sekuler, yaitu terpisahnya agama dan negara. Kemudian berkembang pada tipologi yang lebih moderat, yang oleh beberapa

Jurnal Masyarakat dan Budaya, 11, 1 (2009), hlm. 30. Penelitian M. Syafi'ie ["Pemikiran Organisasi Islam tentang Penerapan Hukum Pidana Islam: Tinjauan Hukum Hak Asasi Manusia”, Undang: Jurnal Hukum, 2, 2 (2019): 225-264] menunjukkan, tuntutan penerapan syariat Islam bahkan juga pada hukum pidana Islam, yang disuarakan oleh organisasi Islam, misalnya Majelis Mujahidin Indonesia dan Jemaah Anshorut Tauhid. 
pemikir Muslim disebut dengan negara tamyiz. Konsep negara tamyiz ini disebut pula sesuai dengan Islam. Muhammad Ali Jum'ah, mantan Mufti Mesir, berpendapat bahwa di dalam Islam tidak dikenal konsep sekuler maupun teokrasi. Negara sekuler tidak diakui Islam, sebab mendekonstruksi peranan agama. Sementara negara teokrasi juga tidak dibenarkan, sebab pemimpin dianggap sebagai wakil Tuhan, yang tentu saja tidak dibenarkan di dalam Islam. ${ }^{7}$

Senada dengan pendapat itu, Muhammad Imarah berpendapat bahwa Islam tidak menganut dan mengakui negara sekuler maupun teorkrasi, melainkan menganut konsep negara tamyiz (baca: pemilahan). Maksudnya adalah negara yang memilah dan memilih soal hubungan antara agama dan negara, sehingga tidak sepenuhnya terpisah seperti halnya sekuler, dan juga tidak sepenuhnya menyatu seperti teokrasi. Saadeddine Othmani juga berpendapat sama mengenai pemilahan (tamyiz) antara urusan agama dan negara. ${ }^{8}$

Akan tetapi tipologi relasi agama dan negara ternyata mengalami perkembangan yang sangat pesat. Ran Hirschl, sebagaimana dikutip Ratno Lukito, mengemukakan sedikitnya ada delapan teori relasi agama dan negara, yaitu: the atheist state; assertive secularis; separation as state neutrality toward religio; weak religious establishment; formal separation with de facto pre-eminence of one denomination; separation alongside multicultural accommodation; religious jurisdictional enclaves; dan strong establishment. ${ }^{9}$ Perkembangan tipologi ini tentu saja menunjukkan diskursus yang masih tidak berkesudahan soal relasi agama dan negara.

Secara historis, kemunculan dan perkembangan paham sekuler merupakan bagian penting yang tidak dapat dipisahkan dari diskursus

7 Sadzali, Relasi Agama dan Negara, hlm. 45.

8 Sadzali, Relasi Agama dan Negara, hlm. 46. Lihat pula: Marwan Bukhari, "Menilai Kembali Negara Islam I", dalam Wacana Pemikiran Reformis Jilid 1, ed. Ahmad Farouk Musa (Kuala Lumpur: Islamic Renaissance Front Berhad, 2012), hlm. 56.

9 Ratno Lukito, "Agama dan Negara di Indonesia: Kontestasi Teori", bahan Diskusi Publik "Negara dan Agama”, diselenggarakan Undang: Jurnal Hukum Fakultas Universitas Jambi, 14/11/2018, https:/ /ujh.unja. ac.id/index.php/home/other/seminar/diskusiNegara-Agama, diakses $10 / 11 / 2020$. 
mengenai relasi agama dan negara. Terjadinya sekularisasi, dalam kaca mata Donald Eugene Smith, ditandai dengan adanya dikotomi antara negara dan agama. Dalam sejarah Eropa, dikotomi yang dimaksud adalah pemisahan negara dari gereja. Sekularisasi juga ditandai dengan pengambilalihan pelaksanaan mengatur masyarakat pada ranah sosioal dan ekonomi oleh negara, yang sebelumnya dilakukan oleh institusi keagamaan. Sekularisasi kemudian juga ditandai adanya pengembangan budaya politik fokusnya kepada tujuan-tujuan yang sifatnya keduniaan (non-transendental), dengan cara membangun argumentasi rasional dan pragmatis. Tanda-tanda terjadinya proses sekularisasi berimplikasi pada pembentukan konsep negara modern, sekalipun juga sangat mungkin tetap ada pemeliharaan atas eksistensi tradisi yang sudah berjalan. ${ }^{10}$

Masih menurut Eugene Smith, sekularisasi betapapun menginginkan lepasnya pemerintahan dari institusi keagamaan, akan tetapi masih ada aspek-aspek ajaran agama yang masih terus hidup dan dilaksanakan, seperti contohnya hukum keluarga. Hukum keluarga bahkan dinilai sebagai tempat pertahanan terakhir bagi eksistensi ajaran agama di dalam sistem kenegaraan. Sementara di sisi lainnya, gejala menonjol yang terjadi adalah adanya delegitimasi agama terhadap pemerintah, baik itu dibarengi atau tidak dibarengi dengan perubahan konstitusi secara resmi. ${ }^{11}$

Objek sekularisasi menyasar kepada berbagai aspek kehidupan manusia. Sekularisasi juga terjadi dengan cukup masif kepada ranah pendidikan, ilmu pengetahuan, teknologi, pembangunan ekonomi serta juga berdampak pada budaya politik. Dalam bentuknya yang radikal, seperti yang diterapkan di Turki dan Meksiko, sekularisasi berujung pada dominasi pemerintahan. ${ }^{12}$

Dalam dunia Islam sendiri, Turki adalah sebuah contoh nyata terjadinya sekularisasi di sebuah negara "agama". Pilihan untuk mengubah sistem pemerintahan monarki-religius menjadi sekuler

10 Donald Eugene Smith, Agama dan Modernisasi Politik: Suatu Kajian Analitis (Jakarta: Penerbit CV. Rajawali, 1985), hlm. 115.

11 Smith, Agama dan Modernisasi Politik, hlm. 7.

12 Smith, Agama dan Modernisasi Politik, hlm. 119. 
adalah sebuah eksperimentasi yang mengagetkan banyak negara ketika itu. Tak dapat dibantah, kehadiran sekularasiasi di Turki bahkan merupakan "keberhasilan" yang membanggakan, walau banyak kecaman dari negara Muslim lainnya, seperti Iran, Mesir, dan Arab Saudi. Turki secara optimis dan konsisten tetap berjalan pada rel pemerintahan non religius, sekalipun masyarakatnya merupakan masyarakat religius. Apa yang dilakukan pemerintah Turki dengan slogan sekularisasi sistem pemerintahan adalah sebuah ajakan bagi keseluruhan negara yang masyarakatnya beragama untuk "membuka mata" bahwa apapun yang dikatakan sebagai proses perubahan dalam masyarakat adalah sebuah keniscayaan, sehingga tidak mungkin ditolak kehadirannya. ${ }^{13}$

Di Asia dan Afrika, sekularisasi disebabkan salah satunya oleh imperialisme Barat. Para penguasa Barat menurunkan raja-raja suci dari tahta mereka (seperti di Birma), mengganti hukum pidana Islam dengan hukum pidana sekuler (seperti di Nigeria bagian utara), menolak untuk memperlakukan warga negara atas dasar tingkatan sosial keagamaan (kasta) dan bahkan menetapkan aturan hukum yang bertentangan dengannya (seperti di India), menghapuskan lembaga-lembaga ekonomi suci dari sistem tuan tanah di kalangan para biksu (seperti di Sri Langka), menganaktirikan sistem pendidikan agama dengan menganakemaskan sekolah-sekolah pemerintah yang bersifat sekuler dan sekolah-sekolah misi Kristen (seperti di Mesir), dan pada umumnya secara drastis memperkecil arti dan pengaruh agama-agama dalam kehidupan sosial maupun politik. ${ }^{14}$

Dalam pandangan Islam, menurut mayoritas pemikir dan ulama Muslim, sekularisme yang bermakna pemisahan agama dari negara itu tidak dapat diterima. Paham sekularisme bertolak belakang dengan ajaran Islam, dimana melingkupi seluruh sendi kehidupan manusia, termasuk dalam hal bernegara. Secara filosofis pun, paham sekularisme ini tidak sejalan dengan pandangan hidup Islam.

Menurut Muhammad Natsir, masing-masing orang memiliki

13 Zuly Qodir, Agama dalam Bayang-Bayang Kekuasaan (Yogyakarta: Interfidei, 2001), hlm. 91-92.

14 Qodir, Agama dalam Bayang-Bayang Kekuasaan, hlm. 118-119 
ideologinya sendiri-sendiri yang menjadi falsafah hidup. Orang Islam, seperti halnya juga orang Kristen dan orang beragama lain, ataupun juga orang fasis dan komunis, memiliki pandangan hidupnya sendirisendiri. Dalam menjalani kehidupan di dunia, orang Islam bercita-cita menjadi hamba yang sesungguhnya, guna menggapai kebahagiaan di dunia dan kemenangan di akhirat. Seorang Muslim tidak akan dapat memisahkan antara kehidupan dunia dan akhirat. Ini adalah ideologi orang Islam. ${ }^{15}$

Dalam pandangan Natsir, dalam pembicaraan relasi agama dan negara, orang kerap lupa bahwa Islam sebagai agama tidak hanya behubungan dengan peribadatan kepada Tuhan saja. Agama Islam mencakup seluruh aspek dan sendi kehidupan manusia. Ajaran Islam juga meliputi kaidah-kaidah yang mengatur relasi manusia dengan manusia yang lainnya yang disebut dengan muamalah, juga mencakup hudud. Islam sudah meletakkan haluan dasar dalam persoalan tersebut yang dapat dirujuk kepada Al-Quran dan Sunnah. Ketentuan-ketentuan di dalam Al-Quran dan Sunnah tersebut harus dapat diterapkan dan dijalankan oleh manusia. Oleh karenanya AlQuran dan Sunnah tidak berdiri sendiri. Agar ketentuan-ketentuan di dalam Al-Quran dan Sunnah itu dapat dijalankan secara maksimal, dibutuhkan suatu kekuatan dan kekuasaan, yang itu disebut sebagai negara. ${ }^{16}$

Dalam pemaknaan Natsir atas demokrasi dari perspektif Islam, hak rakyat untuk mengkritik pemerintah atau negara merupakan hak yang dijamin. Bahkan menurut Natsir, terhadap pemerintah yang zalim, jika tidak cukup dengan kritik, nasihat dan teguran, diperbolehkan juga untuk menggunakan kekuatan dan kekerasan jika diperlukan. ${ }^{17}$ Sehingga kekuasaan benar-benar berada di tangan rakyat. Rakyat tidak boleh mendapatkan perlakuan zalim dari pemerintahnya, karena sejatinya tugas utama pemerintah adalah untuk melayani kepentingan rakyat.

15 M. Natsir, Agama dan Negara dalam Perspektif Islam (Jakarta: Penerbit Media Da'wah, tanpa tahun), hlm. 78.

16 Natsir, Agama dan Negara, hlm. 78-79.

17 Natsir, Agama dan Negara, hlm. 80. 
Penyatuan agama dan negara inijuga dapat dilihat daripandangan Ibnu Taimiyah. Menurutnya, bahkan kebutuhan manusia akan negara didasarkan pada hadis, di samping juga berdasarkan rasio. ${ }^{18}$ Misalnya, Ibnu Taimiyah mengemukakan hadis Rasulullah SAW yang menyatakan: "Apabila ada tiga orang keluar untuk bepergian, hendaklah mereka menjadikan salah satu sebagai pemimpin (amir)" (HR. Abu Dawud). Ibnu Taimiyah, yang mengutip pendapat pada ulama sebelumnya seperti Fudhail bin 'Iyadh dan Ahmad bin Hanbal, juga mengatakan, "Seandainya kami memiliki dakwah yang dituruti dan diikuti, niscaya kami akan menyuruh untuk sebuah kekuasaan”. Ibnu Taimiyah bahkan juga meriwayatkan beberapa riwayat—tanpa menyebutkan sumber perawinya — untuk menambah argumentasinya soal urgensi pemerintahan dan kekuasaan, seperti "Kekuasaan adalah naungan Allah yang ada di bumi" serta riwayat "Enam puluh tahun dari kehidupan seorang pemimpin yang zalim lebih baik daripada satu malam tanpa adanya kepemimpinan." ${ }^{19}$ Dengan begitu Islam tidak dapat dipisahkan dari sebuah negara.

Selanjutnya, Ibnu Taimiyah juga menguatkan argumentasinya itu dengan menyatakan bahwa terdapat sekian banyak tugas keagamaan sesuai ketentuan yang termaktub di dalam al-Quran dan Sunnah tidak dapat dilakukan kecuali oleh negara atau pemerintah. Tugas tersebut seperti menarik zakat, menegakkan hukum pidana bagi pelau kriminal, melakukan jihad, dan lain sebagainya. Semua itu membutuhkan adanya campur tangan dari pemerintah atau negara. Menurutnya, tanpa kekuasaan negara yang memiliki otoritas memaksa, posisi agama dapat berada dalam bahaya, karena sekian banyak ketentuan agama tidak dapat dijalankan. Namun sebaliknya, negara tanpa bimbingan wahyu dan agama, juga dapat menjadi negara yang sangat berbahaya dan berpotensi menjadi tirani. Jadi antara agama dan negara itu sesungguhnya saling melengkapi ${ }^{20}$

18 Khalid Ibrahim Jindan, Teori Pemerintahan Islam Menurut Ibnu Taimiyah, terj. Mufid (Jakarta: PT Rineka Cipta, 1994), hlm. 48-49.

19 Ibnu Taimiyah, Siyasah Syar'iyah: Etika Politik Islam, terj. Rofi' Munawwar (Surabaya: Risalah Gusti, 2005), hlm. 227-228.

20 Jindan, Teori Pemerintahan Islam, hlm. 50. 
Maka di sinilah, menurut Ibnu Taimiyah, letak pentingnya penyatuan antara negara atau kekuasaan dengan agama.

Penyatuan agama dan negara ini bahkan juga telah diakui oleh sarjana-sarjana Barat dan orientalis. Firt Gerald, misalnya, berpendapat bahwa Islam bukan hanya sekadar, melainkan di dalam ajarannya juga mengandung kaidah umum tentang politik. Menurutnya, meskipun terdapat oknum umat Islam yang tak hentinya mencoba memisahkan antara negara dan politik/pemerintahan, akan tetapi konsep Islam sesungguhnya tetap tidak dapat dipisahkan dari negara/politik/pemerintahan. Pakar lainnya seperti Schatt juga berpendapat bahwa Islam tidak hanya sebatas agama yang mengatur antara manusia dengan Tuhan. Islam juga mengatur soal politik serta hukum. Intinya Islam merupakan sistem paripurna, yang mencakup agama serta negara sekaligus. Senada dengan sebelumnya, Stuatman juga berpendapat bahwa Islam merupakan wujud konkrit keserasian dari agama dan negara/ politik. $^{21}$

\section{Polemik Relasi Agama dan Negara sebelum Kemerdekaan}

Polemik relasi agama dengan negara dalam perumusan UUD 1945 ini sebenarnya memiliki akar historis yang cukup lama. Ia tidak hanya bermula ketika badan perumus UUD 1945 dibentuk saja. Polemik ini sudah mengemuka sejak lama sebelum kemerdekaan Indonesia.

Diskursus dan perdebatan terbuka mengenai dasar negara yang berkaitan dengan relasi agama dan negara sudah dimulai setidaknya sejak tahun 1940. Diskursus dan perdebatan tersebut terjadi antara Soekarno dan Muhammad Natsir. Kedua tokoh ini memiliki posisi yang berbeda soal bagaimana sebagainya negara menempatkan agama. Soekarno berpendapat bahwa antara negara dan agama harus dipisah; agama bukanlah urusan negara. ${ }^{22}$ Sementara Natsir berpendapat, agama harus ditempatkan menjadi satu dengan negara;

21 M. Yusuf Musa, Politik dan Negara dalam Islam, terj. M. Thalib (Surabaya: Al-Ikhlas, 1990), hlm. 26-27.

22 Soekarno, Di Bawah Bendera Revolusi (Jakarta: Panitia Penerbitan Di Bawah Bendera Revolusi, 1964), hlm. 407. 
negara harus mengurus agama dan berjalan sesuai dengan ketentuan agama. Pendukung cara pandang Soekarno ini selanjutnya sering disebut sebagai golongan nasionalis, sedangkan pendukung ide Natsir kerap disebut sebagai golongan modernis Islam, yang berpendirian agama Islam juga mengatur negara. ${ }^{23}$

NamunmenurutpenelusuranMahfudMD, perdebatanmengenai agama dan negara itu adalah kelanjutan dari polemik di tahun 1918. Ketika itu terjadi polemik antara Komite untuk Kebangsaan Jawa (Comite Voor het Javanche Nasionalisme) dengan Sarekat Islam. Komite untuk Kebangsaan Jawa berpendirian bahwa politik dan agama haruslah dipisah. Komite ini lahir karena adanya peristiwa Jawi Hisworo pada 1916. Jawi Hisworo yang merupakan koran berbahasa Jawa, melakukan penghinaan terhadap Nabi, dengan menyebut Nabi sebagai pemadat dan pemabuk. Hal ini memicu kebangkitan umat Islam untuk melakukan pembelaan dan perlawanan atas hinaan tersebut. Pembelaan dan perlawanan dari umat Islam itu disambut oleh Jawi Hisworo dengan membentuk Comite voor het Javasche Nationalisme (Panitia Kebangsaan Jawa). Panitia Kebangsaan Jawa ini menuduh orang-orang yang membela umat Islam adalah gerakan asing yang bertujuan untuk menekan kepercayaan yang hidup di Jawa. ${ }^{24}$ Polemik yang terjadi pada medio tahun 1916/1918 ini dapat dikatakan sebagai polemik di internal bangsa Indonesia.

Tentu saja jauh sebelum itu dapat ditelusuri juga bagaimana polemik yang terjadi antara penjajah yang dalam hal ini adalah Belanda, dengan umat Islam dan pribumi soal agama dan negara. Bahkan hubungan negara dan agama ketika itu tidak lagi sekadar polemik, melainkan sudah berada dalam tataran praktik, ketika Belanda memaksakan hukum Barat juga berlaku bagi orang Islam, dan mencoba untuk menghapuskan hukum-hukum agama Islam yang sebelumnya menjadi hukum yang hidup (living law) di tengah masyarakat.

Lima tahun sebelum kemerdekaan, polemik soal relasi agama

23 Moh. Mahfud MD, Dasar dan Struktur Ketatanegaraan Indonesia (Yogyakarta: UII Press, 1993), hlm. 4-5.

24 Mahfud MD, Dasar dan Struktur Ketatanegaraan, hlm. 5-6. 
dan negara mencuat di media massa. Sebagai respons tulisan $\mathrm{KH}$. M. Mansur "Memperhatikan Gerakan Pemuda" pada majalah Pandji Islam dan Adil, Soekarno mengetengahkan "Memudakan Pengertian Islam” pada majalah Pandji Islam. Dalam tulisannya, Soekarno mengkritik kekolotan pemahaman keislaman. Ia menggugah masyarakat Muslim untukmerenungkanulang pemahaman keislaman umat Islam di Indonesia ketika itu. Ia mengajak umat Islam ${ }^{25}$ untuk menengok sejenak kepada beberapa pemikiran Islam yang berkembang di beberapa negara Muslim lainnya, seperti Mesir, Turki, Palestina, dan India. Saat merujuk Turki, Soekarno tidak menyembunyikan kekaguman dan dukungannya kepada Kemal Attaturk pada 1928 yang melakukan sekularisasi. Namun menurut Soekarno, dengan diletakkannya pada urusan personal, bukan berarti Islam telah dihapuskan. Jadi tidak tepat jika menyebut Turki sebagai negara yang anti-agama atau anti-Islam. ${ }^{26}$

Tulisan Soekarno itu disambung lagi dengan tulisannya lainnya dalam Pandji Islam, "Apa Sebab Turki Memisahkan Agama dari Negara?". Ia memperkuat argumentasi yang menyatakan dukungannya terhadap sekularisasi di Turki. Dengan mencoba menunjukkan sikap yang cukup adil, Soekarno mengemukakan bahwa tidak berhak menilai apa yang dilakukan oleh Attaturk di Turki tersebut. Ia menyerahkannya kepada sejarah untuk menilai benar-salahnya. Kemudian di dalam artikel berikutnya "Saya Kurang Dinamis", Soekarno memberi bantahan atas pendapat-pendapat yang menganjurkan agar agama dan negara harus menyatu. Sepintas

25 Perlu diketahui, kondisi dan kecenderungan aspirasi Islam di Indonesia pada abad ke 20 itu, seperti yang dikemukakan Deliar Noer, bahwa pada umumnya di antara bidang-bidang ajaran Islam yang mengambil kedudukan penting adalah fikih dan tarekat yang paling berkembang. Umumnya juga dalam kedua bidang ini terdapat jumud, kebekuan, dengan meng-ia-kan saja apa yang dikatakan guru tanpa mempersoalkannya apakah sesuai dengan ajaran Qur'an dan Sunnah sebagai sumber-sumber utama ajaran Islam. Kaum modernis yang semula menitikberatkan perhatiannya dalam hal agama (dalam arti sempit) memperluas perhatiannya ke bidang sosial dan politik yang kemudian melahirkan keyakinan di kalangan banyak muslim tentang persatuan agama dan politik dalam Islam.

26 Mahfud MD, Dasar dan Struktur Ketatanegaraan, hlm. 7-8. 
Soekarno menilai bahwa upaya untuk membentuk negara Islam itu terlalu memaksakan kehendak atas kaum minoritas beragama, bahkan menuduh sebagai upaya membentuk negara yang diktator. ${ }^{27}$

Tulisan-tulisan Soekarno yang kontroversial itu mendapat tanggapan dan perlawanan dari umat Islam. Salah satu yang mengomentari secara khusus adalah Muhammad Natsir ${ }^{28}$ melalui majalah Pandji Islam dan Al Manar. Dalam artikelnya "Porsekot", Natsir mencurigai pembelaan luar biasa dari Soekarno terhadap Attaturk di Turki. Umat Islam di Indonesia disebutnya tidak ada yang mempersoalkan sekularisasi yang digencarkan oleh Attaturk tersebut; tidak ada yang mengkafirkan Attaturk. Ia justru mempertanyakan mengapa Soekarno begitu membabi-buta membela Attaturk, sementara di Indonesia ketika itu masih belum pernah terdengar kritikan terhadapnya. ${ }^{29}$

Menurut Natsir, kebanyakan orang mungkin lupa bahwa ajaran Islam itu sempurna dan dengan demikian juga meliputi persoalan tentang kenegaraan. Ia menyayangkan pandangan yang cenderung menganggap agama hanyalah soal relasi antara manusia dan Tuhan saja (ibadah). Dalam pemahamannya, Islam sudah mencakup semua aspek kehidupan manusia, mulai dari perihal keyakinan atau akidah, hingga hubungan antar sesama manusia, termasuk dalam hal ini hudud-hudud. Dengan begitu, kedudukan negara sangat penting bagi agama, sepenting kedudukan agama bagi negara. Lebih lanjut ia juga mengomentari soal deskripsi Islam yang cenderung distortif yang muncul di kalangan bangsa Barat, di mana negara Islam digambarkan dengan begitu naif. ${ }^{30}$

\section{Polemik Relasi Agama dan Negara dalam Pembentukan dan Perubahan Konstitusi}

Polemik terbuka di media massa tentang hubungan antara agama

27 Mahfud MD, Dasar dan Struktur Ketatanegaraan, hlm. 9-13.

28 Ketika menanggapi tulisan itu, Natsir menggunakan nama samara dengan nama Muchlis.

29 Mahfud MD, Dasar dan Struktur Ketatanegaraan, hlm. 21.

30 Mahfud MD, Dasar dan Struktur Ketatanegaraan, hlm. 22-23. 
dan negara ini sempat mereda dan sepi. Pasalnya, suasana politik dan hiruk-pikuk Perang Dunia II tidak memberikan peluang atas debat politik seperti itu. Terlebih pemerintah Jepang yang masuk ke Indonesia pada akhir 1941 begitu membatasi gerak politik.

Sebagaimana dikutip Mahfud MD dari Harry J. Benda, menjelang saat-saat rezim Hindia Belanda berakhir, ada tiga golongan utama di Indonesia, yaitu: kaum bangsawan (seperti priyayi Jawa atau hulubalang di Aceh); kaum nasionalis sekuler, yang bergerak melalui organisasi-organisasi yang tidak berdasar agama; dan kaum nasionalis muslim, yang dipimpin dari baik kaum intelektual berpendidikan Barat maupun ulama-ulama tradisional. ${ }^{31}$ Dengan kemenangan Jepang ${ }^{32}$ pada Maret 1942, maka peranan golongan bangsawan berakhir. Dengan demikian hanya ada dua golongan saja lagi yang memainkan peran penting dalam menentukan masa depan Indonesia, yaitu kaum nasionalis sekuler dan kaum nasionalis Muslim. Hal ini berarti pandangan yang diwakili oleh Soekarno dan Natsir terus melanjutkan perjuangannya, hanya saja pada masa-masa pemerintahan Jepang itu debat politik tentang visi masing-masing tidak terungkap lagi sampai akhirnya Jepang membentuk Badan Penyelidik Usaha Persiapan Kemerdekaan (BPUPK) pada April $1945 .^{33}$

Babak baru polemik mengenai relasi negara dan agama muncul kembali saat BPUPK dibentuk. Namun pembentukan BPUPK ini tidak dapat dilepaskan dari janji Jepang yang akan memberikan kemerdekaan kepada bangsa Indonesia, yaitu janji dari Perdana Menteri Jepang, Kuniaki Kaiso, pada 7 September 1944. Sebagaimana dikutip Jimly Asshiddiqie dari Pringgodigdo, Jepang dengan janji

31 Mahfud MD, Dasar dan Struktur Ketatanegaraan, hlm. 28. Lihat pula B.J. Boland, Pergumulan Islam di Indonesia 1945-1972, terj. Saafroedin Bahar (Jakarta: Grafiti Press, 1985), hlm. 9.

32 Menurut Boland, agama Islam dimanfaatkan oleh Jepang guna melanggengkan tujuan perangnya. Maka tidaklah mengherankan bila di permulaan pemerintahannya, kelompok nasionalis Islam banyak mendapatkan manfaat secara politis, seperti didirikannya Kantor Urusan Agama Indonesia, Masyumi, termasuk mungkin Hizbullah. Lihat: Boland, Pergumulan Islam di Indonesia, hlm. 9-16.

33 Mahfud MD, Dasar dan Struktur Ketatanegaraan, hlm. 28-29. 
tersebut sebenarnya ingin agar bangsa Indonesia dapat membantu tentara Jepang menghadapi tentara Sekutu, yang ketika itu kekuataan tentara Sekutu dinilai semakin kuat, sehingga tentara Jepang semakin terdesak. ${ }^{34}$

Berdasarkan janji yang disampaikan di hadapan resepsi istimewa The Imperial Dies ke 85 itu, maka dibentuklah satu kepanitiaan "Dokuritzu Zyumbi Tyosokai", atau yang dikenal dengan BPUPK, pada 29 April 1945. Panitia ini beranggotakan 62 orang, dan mulai bersidang pada 29 Mei 1945, sehari setelah pelantikan secara resmi. Sidang paripurna diselenggarakan sebanyak dua kali, yakni 29 Mei-1 Juni 1945 untuk sidang pertama, dan 10-16 Juli 1945 untuk sidang kedua. $^{35}$

Pada sidang pertama sudah mulai ditarik picu perdebatan yang menimbulkan kembali perdebatan mengenai hubungan agama dengan negara. Adapun pemicu perdebatan tersebut adalah satu pertanyaan yang sangat mendasar dan penting ketua BPUPK Radjiman Wedyodiningrat, "Atas weltanschauung yang manakah negara baru ini didasarkan?” Pertanyaan itu mengenai dasar negara Indonesia yang nantinya dibentuk. Tiga anggota BPUPK yang mengemukakan pendapatnya, yaitu Mr. Muhammad Yamin pada 29 dan 31 Mei 1945, Prof. Soepomo pada 31 Mei 1945, dan Ir. Soekarno pada 1 Juni $1945 .^{36}$

Dalam menanggapi pertanyaan Radjiman tersebut, anggota BPUPKI terpecah menjadi dua kelompok besar. Ada yang mengusulkan agar Indonesia yang akan berdiri dan merdeka nanti dibentuk berdasarkan kebangsaan dan tanpa ikatan tertentu dengan ideologi keagamaan, termasuk dalam hal ini Islam. Kelompok lainnya

34 Jimly Asshiddiqie, Konstitusi dan Konstitusionalisme Indonesia (Jakarta: Konstitusi Press, 2005), hlm. 39.

35 J.C.T. Simorangkir, Penetapan UUD: Dilihat dari Segi Ilmu Hukum Tata Negara Indonesia (Jakarta: PT. Gunung Agung, 1984), hlm. 9-12.

36 Mahkamah Konstitusi Republik Indonesia, Naskah Komprehensif Perubahan Undang-Undang Dasar Negara Republik Indonesia Tahun 1945, Buku VIII: Warga Negara dan Penduduk, Hak Asasi Manusia dan Agama (Jakarta: Sekretariat Jenderal dan Kepaniteraan Mahkamah Konstitusi, edisi revisi, 2010), hlm. 87-88. 
mengusulkan agar Islam menjadi dasar negara. Sebelumnya, pihak Jepang sendiri, sebagai pelopor dibentuknya BPUPK, menyatakan diri netral soal Islam dan dasar negara. Sikap Jepang ini disampaikan oleh Jenderal Nishimura, Kepala Departemen Umum Pemerintahan Pendudukan Jepang, kepada para anggota BPUPKI pada 13 Mei 1945. Nishimura menyatakan:

"Kami mengetahui benar-benar betapa berhubungan di antara bangsa Indonesia dan Islam, tetapi tentang bagaimanakah mestinya kedudukan agama Islam di dalam negara baru serta perhubungan di antara agama Islam dengan agama lain, pihak Nippon tidaklah sekali-kali mempunyai suatu gambaran atau rencana ... Tentang soal ini, saya berpendapat bahwa bangsa Indonesia sendiri tentu telah insaf dan paham benar-benar, apakah yang terlebih cocok dan sesuai dengan keadaan di Jawa khususnya dan keadaan di Indonesia umumnya pada saat ini." ${ }^{37}$

Pada 29 Mei, Yamin hanya menyampaikan bahwa Indonesia yang merdeka nanti harus berbudi luhur dan peradabannya mempunyai Tuhan Yang Maha Esa. Yamin mengatakan:

“... maka lebih dahulu kita sekali lagi jakinkan, bahwa bangsa Indonesia jang akan bernegara merdeka itu ialah bangsa jang beradab luhur, dan peradabannya itu mempunyai Tuhan Jang Maha Esa. Oleh sebab itu, maka dengan sendirinja kita insjaf, bahwa Negara Kesedjahteraan Indonesia Merdeka itu akan ber-Ketuhanan. Tuhan akan melindungi Negara Indonesia Merdeka itu." ${ }^{38}$

Pada 31 Mei, Soepomo berpidato dan menyampaikan pendapatnya agar Indonesia yang akan merdeka nanti menjadi negara nasional yang bersatu, dengan adanya pemisahan antara agama dan negara. Berikut penggalan dari pidato Soepomo yang dikutip Yamin dan juga dinukil dalam Naskah Komprehensif Perubahan UUD 1945 terbitan Mahkamah Konstitusi RI:

"Oleh karena itu saja mengandjurkan dan saja mupakat dengan pendirian jang hendak mendirikan negara nasional jang bersatu dalam arti, totaliter seperti jang saja uraikan tadi, jaitu negara jang tidak akan mempersatukan

37 Ahmad Syafii Maarif, Islam dan Masalah Kenegaraan: Studi tentang Percaturan dalam Konstituante (Jakarta: LP3ES, 1996), hlm. 102; Mahkamah Konstitusi, Naskah Komprehensif Perubahan, hlm. 87-88.

38 Muhammad Yamin, Naskah Persiapan Undang-Undang Dasar 1945, Jilid 1 (Jakarta: tanpa penerbit, cetakan kedua, 1971), hlm. 94; Mahkamah Konstitusi, Naskah Komprehensif Perubahan, hlm. 88. 
diri dengan golongan jang terbesar, akan tetapi jang akan mengatasi segala golongan dan akan mengindahkan dan menghormati keistimewaan dari segala golongan, baik golongan jang besar maupun golongan jang ketjil. Dengan sendirinya dalam negeri nasional jang bersatu itu, urusan agama akan terpisah dari urusan negara dan dengan sendirinya dalam negara nasional jang bersatu itu urusan agama akan diserahkan kepada golongan-golongan agama jang bersangkutan. Dan dengan sendirinja dalam negara sedemikian seseorang akan merdeka memeluk aama jang disukainja." ${ }^{39}$

Pada 1 Juni, Soekarno menyampaikan pidatonya yang mengusulkan prinsip ketuhanan untuk negara Indonesia. Sebagaimana dikutip oleh Yamin, beginilah penggalan dari pidato Soekarno:

"Prinsip Ketuhanan! Bukan sadja bangsa Indonesia ber-Tuhan, tetapi masing-masing orang Indonesia hendaknja ber-Tuhan. Tuhannja sendiri. Jang Kristen menjembah Tuhan menurut petundjuk Isa al Masih, jang belum ber-Tuhan menurut petundjuk Nabi Muhammad s.a.w., orang Buddha mendjalankan ibadatnja menurut kitab-kitab yang ada padanja. Tetapi marilah kita semuanja ber-Tuhan. Hendaklah Negara Indonesia ialah negara jang tiap-tiap orangnja dapat menjembah Tuhannja dengan tjara jang leluasa. ... Marilah kita di dalam Indonesia Merdeka jang kita susu ini, sesuai dengan itu, menjatakan: bahwa prinsip kelima daripada Negara kita ialah ke-Tuhanan jang berkebudajaan, ke-Tuhanan jang berbudi pekerti jang luhur, ke-Tuhanan jang hormat-menghotmati satu sama lain. Hatiku akan berpesta raja, djikalau saudara-saudara menjetudjui bahwa Negara Indonesia Merdeka berazaskan ke-Tuhanan Jang Maha Esa!"40

Menurut Mahfud MD, kemungkinan wakil-wakil Islam mengemukakan usulannya tentang dasar negara Islam itu pada hari kedua (30 Mei 1945), sebab pidato Soepomo dan Soekarno yang bernada jawaban dan sekaligus penolakan yang dimuai dalam buku Yamin itu disampaikan pada 31 Mei dan 1 Juni 1945; sementara di dalam buku Yamin tidak ditemukan catatan tentang pembicaraan yang terjadi pada 30 Mei $1945 \mathrm{itu}$. Bagaimana golongan Islam berjuang dan berusaha meyakinkan dalam BPUPKI tentang kemungkinan Islam mejadi dasar negara sulit diketahui dengan pasti karena pidato-

39 Yamin, Naskah Persiapan Undang-Undang Dasar, hlm. 117; Mahkamah Konstitusi, Naskah Komprehensif Perubahan, hlm. 88-89.

40 Yamin, Naskah Persiapan Undang-Undang Dasar, hlm. 77-78; Mahkamah Konstitusi, Naskah Komprehensif Perubahan, hlm. 88. 
pidato golongan Islam dalam Badan tersebut tidak ditemukan lagi naskahnya. Tetapi tulisan Ki Bagoes Hadikoesoemo yang terbit tahun 1945 kiranya bisa mewakili pandangan itu.

Menurut Soepomo, sebagaimana dikutip Mahfud MD, kelompok yang menolak menjadikan Islam sebagai dasar negara Indonesia yang akan merdeka disebabkan beberapa alasan. ${ }^{41}$ Pertama, adanya kekhasan yang dimiliki Indonesia dan itu membedakannya dengan negara-negara mayoritas Muslim lainnya seperti Mesir, Arab Saudi, Irak dan sebagainya. Padahal dasar negara itu haruslah sesuai dengan kekhasan masyarakatnya. Kedua, belum adanya kesepakatan di berbagai negara Islam mengenai bagaimana seharusnya bentuk negara hukum yang sesuai dengan zaman modern. Apakah hukum syariat boleh diubah dan disesuaikan dengan kebutuhan zaman misalhnya, masih terdapat pertentangan: ada yang mengatakan boleh dan ada yang mengatakan tidak boleh. Maka jika kita akan mendirikan negara Islam akan timbullah pertentangan dalam masyarakat dan panitia penyelidikan akan sulit memperbincangkan secara baik. Ketiga, adanya anggapan bahwa dengan menjadikan Islam sebagai dasar negara berarti tidak menjadikan negara Indonesia sebagai negara persatuan, akan tetapi hal itu berarti mendirikan negara yang mempersatukan diri dengan golongan terbesar yaitu golongan Islam. Hal ini akan memberatkan kelompok minoritas beragama karena akan timbul perasaan minder. Meskipun adanya jaminan dan perlindungan kebebasan beragama, tapi hal tersebut tidak akan menjadikan kelompok minoritas beragama itu akan menyerahkan diri secara total kepada negara Indonesia. Dengan alasan-alasan itulah Soepomo mengatakan bahwa gagasan yang ingin menjadikan Islam sebagai dasar negara itu bertentangan dengan gagasan negara persatuan yang sudah lama dicita-citakan oleh bangsa Indonesia.

Namun sayangnya, sidang pertama BPUPK masih belum menghasilkan kesepakatan bulat mengenai dasar negara. Antara pandangan yang menginginkan Islam dijadikan sebagai dasar negara dan pandangan yang menginginkan agar negara tidak didasarkan

41 Mahfud MD, Dasar dan Struktur Ketatanegaraan, hlm. 32-39. 
pada ideologi agama tertentu masih tidak dapat dipertemukan titik kesepakatannya ${ }^{42}$ Tawar menawar masih terjadi hingga dibentuknya panitia kecil beranggotakan 38 orang, dan kemudian dibentuk lagi Panitia Sembilan yang anggotanya terdiri dari: Soekarno, Hatta, Wachid Hasyim, A. Maramis, Abikusno Tjokosujoso, AK. Mudzakir, H. Agus Salim, Achmad Subardjo, dan Moh. Yamin. Secara komposisi keterwakilan kelompok dan pandangan, Panitia Sembilan telah mengakomodir kelompok yang berpandangan sebaiknya Islam dijadikan dasar negara dan kelompok yang tidak menginginkannya. Bahkan juga terdapat perwakilan dari kelompok non-Muslim. ${ }^{43}$

Setelah melewati pembahasan yang mendalam dan kritis, maka kemudian pada 20 Juni $1945^{44}$ Panitia Sembilan akhirnya berhasil menyepakati Mukaddimah UUD yang dikenal dengan Piagam Jakarta. Kesepakatan ini disebut kesepakatan luhur (modus vivendi), karena merupakan kesepakatan bersama semua kelompok yang tadinya memiliki pandangan berbeda, serta sebagai bentuk kompromi. ${ }^{45}$ Terang saja, dalam forum sidang lengkap kedua BPUPK (10-16 Juni 1945) Soekarno sebagai ketua Panitia Kecil mempertahankan mati-matian hasil keputusan yang berupa Piagam Jakarta itu, sebab menurutnya Piagam Jakarta itu merupakan hasil modus, kesepakatan antara pihak nasionalis Islam dan pihak nasionalis sekuler yang

42 Masykuri Abdillah, Demokrasi di Persimpangan Makna Respons Intelektual Muslim Indonesia terhadap Konsep Demokrasi (1966-1993) (Yogyakarta: Tiara Wacana, 1999), hlm. 32.

43 Ada pandangan bahwa perbandingan komposisi anggota Panitian Sembilan ini adalah 4:5 antara kubu nasionalis Islam dan nasionalisme sekuler. Empat orang, yakni: Wachid Hasyim, AK. Mudzakir, Agus Salim, Abikusno Tjokrosujono adalah wakil-wakil golongan Islam. Sedangkan lima orang sisasnya mewakili golongan nasionalis sekuler. Namun ada juga pandangan bahwa komposisinya adalah 4:4, karena Soekarno ditempatkan pada posisi netral dan menjadi penengah antara kedua golongan tersebut.

44 Data berbeda dikutip oleh Mahfud MD yang menyebutkan kesepakatan itu terjadi pada 22 Juni 1945. Mahfud MD, Dasar dan Struktur Ketatanegaraan, hlm. 44-45.

45 Endang Saifuddin Anshari, Piagam Jakarta 22 Juni 1945 dan Sejarah Konsesus Nasional antara Nasionalis Islami dan Nasionalis Sekuler tentang Dasar Negara Republik Indonesia 1945-1959 (Jakarta: Rajawali Press, 1986), hlm. 29-32. 
dicapai dengan susah payah. ${ }^{46}$

Sampai di sini, pekerjaan dan tugas BPUPK dianggap selesai oleh Pemerintah Balatentara Pendudukan Jepang. Untuk lebih mengkonkretkan persiapan segala sesuatu tentang kemerdekaan yang akan "dihadiahkan" oleh Jepang, maka dibentuklah Dokuritau Zyundi Iinkai (Panitia Persiapan Kemerdekaan Indonesia, PPKI). Pembentukan PPKI ini disetujui oleh Panglima Tertinggi Balatentara Dai Nippon di Asia Selatan, Jenderal Besar Terauchi, pada 7 Agustus 1945, yang awalnya direncanakan pada pertengahan Agustus. Pada 9 Agustus 1945, Soekarno, Moh. Hatta dan K.R.T Radjiman Wediodiningrat menghadap Jenderal Besar Terauchi di Saigon untuk menerima secara langsung keputusan pembentukan PPKI. Soekarno diangkat sebagai ketua dan Moh. Hatta sebagai wakilnya. Namun akhirnya peta berubah setelah Jepang menyerah kepada Sekutu pada 15 Agustus 1945 akibat luluh lantahnya kota Hiroshima dan Nagasaki. Dengan demikian janji Jepang untuk "memberikan kemerdekaan" kepada Indonesia itu terang saja tidak dapat terwujud. Dengan segala keberaniannya, akhirnya bangsa Indonesia memproklamirkan kemerdekaannya secara independen pada 17 Agustus 1945. ${ }^{47}$

Keesokan harinya setelah Proklamasi, 18 Agustus 1945, semua anggota PPKI bersidang untuk membahas UUD serta melakukan pemilihan Presiden dan Wakil Presiden. Penetapan UUD, Presiden dan Wakil Presiden itu memang harus diadakan secepatnya karena setelah diproklamasikan negara Indonesia harus mempunyai UUD dan Presiden/Wakil Presiden yang disahkan oleh PPKI. Oleh Yamin disebutkan, rapat 18 Agustus 1945 itu direncanakan dimulai pukul 09.30, tetapi terlambat sekitar 2 jam. Ada dugaan kuat, keterlambatan itu disebabkan terjadinya lobbying antara Hatta dan sejumlah perwakilan kelompok Islam untuk mengubah beberapa ketentuan rancangan Mukaddimah dan UUD yang telah disetujui oleh BPUPK. Dugaan ini diperkuat oleh kenyataan bahwa ketika rapat dibuka, Hatta

46 Irfan Idris, Islam dan Konstitusionalisme: Kontribusi Islam dalam Penyusunan Undang-Undang Dasar Indonesia Modern (Yogyakarta: AntonyLib, 2009), hlm. 57.

47 Simorangkir, Penetapan UUD, hlm. 16-18. 
langsung dipersilakan mengusulkan perubahan-perubahan setelah terlebih dahulu Soekarno meminta sidang untuk tidak bertele-tele dan berbicara garis besar saja. Hatta langsung mengusulkan empat perubahan terhadap naskah Mukaddimah (Piagam Jakarta) terhadap naskah UUD yang telah disetujui pada 16 Juni $1945,{ }^{48}$ yaitu ${ }^{49}$ pertama, istilah 'Mukaddimah' diganti dengan istilah 'Pembukaan'; kedua, Sila Pertama kandungan Pancasila yang semula dalam Piagam Jakarta berbunyi "Ketuhanan dengan kewajiban menjalankan syariat Islam bagi pemeluk-pemeluknya” diganti menjadi "Ketuhanan Yang Maha Esa”; ketiga, Pasal 6 Di Batang Tubuh UUD yang awalnya berbunyi "Presiden ialah orang Indonesia asli yang beragama Islam" diubah menjadi "Presiden ialah orang Indonesia asli"; dan keempat, Pasal 28 Batang Tubuh UUD yang awalnya berbunyi "Negara berdasarkan atas Ketuhanan dengan kewajiban menjalankan syariat Islam bagi pemeluk-pemeluknya" diubah menjadi "Negara berdasarkan Ketuhanan Yang Maha Esa.” Perubahan yang keempat, menyangkut Pasal 28, kemudian digeser menjadi Pasal 29.

Selain ulusan perubahan tersebut, masih ada usul-usul perubahan lain dari Ki Bagoes Hadikoesoemo yang meminta penggunaan diksi "menurut dasar" sesudah kata-kata "Ketuhanan Yang Maha Esa" dihilangkan saja. Kemudian I Gusti Ketut Pudja mengusulkan agar kalimat "Atas berkat rahmat Allah" pada alenia III Mukadimah UUD diganti dengan kalimat "Atas berkat rahmat Tuhan". Usulan I Gusti Ketut Pudjo ini diterima dan disepakati agar diganti menjadi "Atas berkat rahmat Tuhan Yang Maha Kuasa”. Usul-usul perubahan itu

48 Persiapan rancangan UUD dilakukan dalam sidang kedua BPUPK dengan dibentuk suatu Panitia Hukum Dasar yang terdiri dari 19 orang, termasuk Ir. Soekarno sebagai ketua. Tugas panitia ini adalah untuk merancang Undang-Undang Dasar. Kemudian untuk memperlancar penyelesaian tugas tersebut, maka dibentuk lagi Panitia Kecil yang berjumlah tujuh orang, yakni: Soepomo sebagai ketua, Wongsonagoro, A. Soebardjo, A. Maramis, R. Pandji Singgih, Agus Salim dan Soekiman. Adapun tugas Panitia Kecil ini adalah merancang Undang-Undang Dasar dengan memperhatikan segala pendapat yang telah dikemukakan oleh para anggota, baik dalam sidang BPUPKI maupun yang dikemukakan oleh para anggota dalam rapat Panitia Hukum Dasar.

49 Simorangkir, Penetapan UUD, hlm. 51-52. 
akhirnya diterima oleh para anggota sidang PPKI. Soekarno sebagai ketua membacakan perubahan tersebut. Tetapi mungkin karena kekhilafan atau karena sebab lain yang belum diketahui, ternyata naskah resmi yang telah diundangkan atau dimuat dalam Berita Republik Indonesia Nomor 7 Tahun 1946 tetap tertulis kalimat "Atas berkat rahmat Allah" pada alinea III dan tidak tertulis "Atas berkat rahmat Tuhan" seperti yang telah disetujui pada 18 Agustus $1945 .^{50}$

Begitulah akhir dari polemik soal relasi agama dan negara pada pembentukan UUD 1945 di awal kemerdekaan. Rumusan akhir ketentuan yang di dalam UUD 1945 yang berkaitan dengan relasi agama dan negara adalah:

1. Sila Pertama Pancasila yang terkandung di dalam Pembukaan UUD 1945 adalah: "Ketuhanan Jang Maha Esa."

2. Pasal 29 ayat (1) UUD 1945 berbunyi: "Negara berdasarkan atas Ke-Tuhanan Jang Maha Esa.

3. Pasal 29 ayat (2) UUD 1945 berbunyi: "Negara mendjamin kemerdekaan tiap-tiap penduduk untuk memeluk agamanja masing-masing dan untuk beribadat menurut agamanja dan kepertjajaanja itu.'

UUD 1945 yang disahkan oleh PPKI tersebut sifatnya sementara. Hal ini dapat dilihat di dalam Aturan Tambahan yang menyatakan bahwa dalam enam bulan sesudah dibentuk, Majelis Permusyawaratan Rakyat bersidang untuk menetapkan UUD. Selain itu Soekarno juga menyatakan di dalam sidang PPKI pada 18 Agustus 1945, UUD 1945 yang disahkan tersebut hanya sekadar UUD sementara dan UUD kilat. ${ }^{51}$ Dengan begitu masih terdapat upaya-upaya pembentukan konstitusi yang lain, dan seperti yang diketahui bersama, konstitusi lain yang pernah menjadi dasar negara selain UUD 1945 adalah Konstitusi RIS dan UUDS 1950.

Jika melihat pada pengaturan mengenai agama di dalam dua Konstitusi tersebut, maka secara umum tidak ada perubahan berarti dari konsep relasi agama dan negara yang sudah disepakati di dalam UUD 1945. Di dalam Konstitusi RIS, mengenai agama diatur dalam

50 Simorangkir, Penetapan UUD, hlm. 52-53.

51 Idris, Islam dan Konstitusionalisme, hlm. 60. 
Pasal 18, yang bunyinya sebagai berikut:

"Setiap orang berhak atas kebebasan pikiran keinsyafan batin dan agama, hak ini meliputi kebebasan bertukar agama atau keyakinan begitu pula kebebasan menganut agama atau keyakinannya, baik sendiri maupun bersama-sama dengan orang lain, baik di muda umum maupun dalam lingkungannya sendiri dengan jalan mengajarkan, mengamalkan beribadat mentaati perintah dan aturan-aturan agama, serta dengan jalan mendidik anak-anak dalam iman dan keyakinan orang tua mereka." ${ }^{52}$

Begitu juga dalam UUDS 1950, tidak terjadi pergeseran konsep relasi agama dan negara. Negara memberikan jaminan kebebasan beragama, tanpa menetapkan agama tertentu sebagai dasar negara. Mengenai agama diatur dalam Pasal 18 yang berbunyi "Setiap orang berhak atas kebebasan agama, keinsyafan batin dan pikiran." Pada Mukaddimah UUDS 1950 juga dinyatakan bahwa negara "berdasarkan pengakuan ke-Tuhanan Yang Maha Esa."

Akan tetapi sebenarnya perdebatan mengenai konsep negara terulang kembali di dalam Konstituante. Dengan bermodal 230 kursi di Konstituante hasil Pemilu $1955,{ }^{53}$ dalam upaya pembentukan UUD baru, kelompok Islam kembali memperjuangkan syariat Islam. Perdebatan soal dasar negara kembali pecah. Kelompok Islam di Konstituante berpendirian dengan Pancasila yang dirumuskan di dalam Piagam Jakarta, sedangkan kelompok lainnya menolak. Menurut Adnan Buyung Nasution, perdebatan mengenai dasar negara di Konstituante menunjukkan sikap yang konfrontatif di antara pendukung ideologi-ideologi yang berbeda. Masing-masing kelompok merasa pendapatnya yang paling benar dan unggul. ${ }^{54}$ Hingga pada akhirnya, Presiden Soekarno mengeluarkan Dekrit Presiden pada 5 Juli 1959 yang mengembalikan konstitusi kepada UUD 1945 serta membubarkan Konstituante.

Kemudian ketika UUD 1945 berlaku kembali dan mengalami amandemen setelah reformasi 1998, pembahasan mengenai agama

52 Mahkamah Konstitusi, Naskah Komprehensif Perubahan, hlm. 91.

53 Idris, Islam dan Konstitusionalisme, hlm. 105.

54 Adnan Buyung Nasution, Aspirasi Pemerintahan Konstituasional di Indonesia: Studi Sosio-Legal atas Konstituante (Jakarta: Pustaka Utama Grafti, 1995), hlm. 66 . 
sebenarnya sempat muncul kembali. Pada awalnya dalam rangkaian persidangan dan pembahasan, secara umum pembahasan mengenai agama lebih kepada pemaknaan atas Pasal 29 UUD 1945. Akan tetapi kemudian dalam agenda Rapat PAH I BP MPR-RI ke-44 yang dilaksanakan pada 14 Juni 2000, muncul usulan agar menghidupkan kembali kata 'syariat Islam'. Usulan ini datang dari F-PBB yang mengusulkan agar Pasal 29 UUD 1945 ayat (1) diubah dan ditambahkan kata 'syariat Islam', sehingga berbunyi: "Negara berdasarkan atas Ketuhanan Yang Maha Esa dengan kewajiban menjalankan syariat Islam bagi para penganutnya." Usulan ini kemudian didukung dan dikuatkan oleh F-PPP yang juga mengusulkan agar Pasal 29 ayat (1) menjadi: "Negara berdasarkan atas Ketuhanan Yang Maha Esa dengan kewajiban menjalankan syariat Islam bagi pemeluk-pemeluknya." ${ }_{55}$ Sebagian besar fraksi lainnya menolak usulan tersebut. Sempat terjadi perdebatan alot dan beradu argumentasi dan belum menemukan kata sepakat pada rapat tersebut. Setelah melalui pembahasan mendalam antarfraksi selama berhari-hari, PAH I BP MPR berhasil menyepakati rumusan alternatif Pasal 29 ayat (1) UUD 1945, sebagaimana Tabel $1 .^{56}$

Munculnya rumusan alternatif mengenai Pasal 29 ayat (1) ini menandakan bahwa polemik relasi agama dan negara belum usai. Meski juga perlu digarisbawahi bahwa perdebatan pada amandemen UUD 1945 ini tidak lagi soal dasar negara. Semua fraksi sepakat bahwa dasar negara Indonesia adalah Pancasila. Adapun perdebatan yang terjadi lebih pada diskursus pemaknaan dari Pancasila dan implementasinya dalam Pasal 29. Terdapat perbedaan kondisi komposisi golongan-ideologis antara BPUPK dan PPKI dengan komposisi saat pembahasan amandemen UUD 1945 di MPR RI. Pada BPUPK dan PPKI, golongan nasionalis Islam berhadapan dengan golongan nasionalis sekuler, sedangkan pada pembahasaan

55 Sekretariat Jenderal Majelis Permuswayaratan Rakyat Republik Indonesia, Risalah Perubahan Undang-Undang Dasar Negara Republik Indonesia Tahun 1945 (1999-2002) Tahun Sidang 2000 Buku Lima (Jakarta: Sekretariat Jenderal MPR-RI, 2008), hlm. 445-446 dan 452-453; Mahkamah Konstitusi, Naskah Komprehensif Perubahan, hlm. 409 dan 419.

56 Mahkamah Konstitusi, Naskah Komprehensif Perubahan, hlm. 486 dan 487. 
Tabel 1. Rumusan alternatif Pasal 29 ayat (1) UUD 1945

\begin{tabular}{|c|c|}
\hline Rumusan Alternatif & Fraksi Pendukung \\
\hline $\begin{array}{l}\text { Alternatif 1: } \\
\text { "Negara berdasarkan atas Ketuhanan } \\
\text { Yang Maha Esa." (tetap) }\end{array}$ & $\begin{array}{l}\text { F-PDIP (Fraksi Partai Demokrasi } \\
\text { Indonesia Perjuangan) } \\
\text { F-PG (Fraksi Partai Golongan } \\
\text { Karya) } \\
\text { F-UG (Fraksi Utusan Golongan), } \\
\text { F-TNI/ Polri, F-PDU (Fraksi } \\
\text { Perserikatan Daultan Ummat) } \\
\text { F-PDKB (Fraksi Partai Demokrasi } \\
\text { Kasih Bangsa) }\end{array}$ \\
\hline $\begin{array}{l}\text { Alternatif 2: } \\
\text { "Negara berdasarkan atas Ketuhanan } \\
\text { Yang Maha Esa dengan kewajiban } \\
\text { menjalankan syariat Islam bagi peme- } \\
\text { luk-pemeluknya." }\end{array}$ & $\begin{array}{l}\text { F-PPP (Fraksi Partai Persatuan } \\
\text { Pembangunan) } \\
\text { F-PBB (Fraksi Partai Bulan } \\
\text { Bintang) }\end{array}$ \\
\hline $\begin{array}{l}\text { Alternatif 3: } \\
\text { "Negara berdasar atas Ketuhanan } \\
\text { Yang Maha Esa dengan kewajiban } \\
\text { menjalankan ajaran agama bari masing- } \\
\text { masing pemeluknya." }\end{array}$ & $\begin{array}{l}\text { F-KB (Fraksi Kebangkitan Bangsa) } \\
\text { F-Reformasi }\end{array}$ \\
\hline $\begin{array}{l}\text { Alternatif 4: } \\
\text { "Negara berdasar atas Ketuhanan } \\
\text { Yang Maha Esa, kemanusiaan yang } \\
\text { adil dan beradab, Persatuan Indonesia, } \\
\text { Kerakyatan yang dipimpin oleh } \\
\text { hikmat kebijaksanaan dalam permu- } \\
\text { syawaratan/perwakilan, dan Keadilan } \\
\text { Sosial bagi Seluruh Rakyat Indonesia." }\end{array}$ & $\begin{array}{l}\text { F-KKI (Fraksi Kesatuan } \\
\text { Kebangsaan Indonesia) }\end{array}$ \\
\hline
\end{tabular}

amandemen UUD 1945 di MPR RI, umat Islam tidak satu suara dalam memperjuangkan frasa 'syariat Islam' dalam Pasal 29.

Perdebatan mengenai empat usulan rumusan alternatif itu ternyata tidak menemukan kesepakatan dan tidak bisa dikompromikan, sehingga direkomendasikan untuk dibahas lebih lanjut dalam ST MPR RI Tahun 2001 dan ST MPR Tahun 2002. Merujuk pada Naskah Komprehensif Perubahan Undang-Undang Dasar Negara Republik Indonesia Tahun 1945 dan Risalah Perubahan UndangUndang Dasar Negara Republik Indonesia Tahun 1945 (1999-2002), perdebatan mengenai empat usulan rumusan alternatif Pasal 29 
tetap berlangsung dengan sengit, tidak menemukan kata sepakat dan kompromi, hingga pada akhirnya Rapat Paripurna ST MPR Tahun 2002 pada 1 Agustus 2002 memutuskan bahwa Pasal 29 UUD 1945 tidak mengalami perubahan. Ketua Sidang M. Amien Rais menutup rapat dengan mengatakan:

"Perkumpulan bangsa kita dalam ikhtiar meletakkan hubungan ahama dan negara pada momentum Sidang Tahunan Majelis sekarang ini dapat disepakati dengan tetap pada rumusan Negara berdasarkan Ketuhanan Yang Maha Esa Pasal 29 Ayat (1) dan negara menjamin kemerdekaan tiap-tiap penduduk untuk memeluk agamanya masing-masing dan untuk beribadah menurut agamanya dan kepercayaannya, hanya itu pada Pasal 29 Ayat (2). Rumusan yang merupakan kesepakatan luhur para pendiri negara pada tahun 1945 ini dipandang paling tepat untuk mengayomi semua aspirasi dan pemahaman keagamaan menurut masyarakat Indonesia, kami sangat menghargai seluruh fraksi MPR terutama fraksi pengusul tujuh kata Piagam Jakarta yang telah menunjukkan jiwa besar dalam memperjuangkan aspirasi konstituennya sehingga tercapai kesepahaman untuk tidak melakukan voting terhadap Pasal 29 Ayat (1) dan Ayat (2) ini." 57

\section{E. Implikasi Polemik Relasi Agama dan Negara dalam Pembentukan dan Perubahan Konstitusi}

Dengan memperhatikan perdebatan mengenai dasar negara dan pengaturan agama dalam perjalananan pembentukan dan perubahan UUD 1945, terlihat jelas efek dari polemik dan diskursus mengenai relasi agama dan negara. Polemik ini setidaknya dipengaruhi oleh cara pandang masing-masing kelompok soal posisi agama terhadap negara dan sebaliknya. Dalam bahasa lain, polemik ini muncul sebagai manifestasi dari ideologi atau cara pandang yang dianut mengenai relasi agama dan negara. Perbedaan ideologi mengenai cara pandang relasi agama dan negara sudah dipaparkan pada bagian awal artikel ini.

Cara pandang ideologis mengenai relasi agama dan negara ternyata sangat berpengaruh dan sangat menentukan dalam perumusan suatu konstitusi, khususnya dalam konteks kajian ini adalah

57 MPR-RI, Risalah Perubahan Undang-Undang Dasar, hlm. 794-795; Mahkamah Konstitusi, Naskah Komprehensif Perubahan, hlm. 595. 
konstitusi Indonesia UUD 1945. Perbedaan ideologis ini sangat tampak tulus dan murni ketika perumusan UUD 1945 menjelang kemerdekaan. Pilihan politik soal dasar negara dan relasinya dengan agama murni berlatar belakang ideologi. Sehingga sangat tidak mudah untuk menyatukan ideologi yang berbeda ke dalam sebuah kesepakatan bersama, terlebih menyangkut dasar negara yang akan mempengaruhi jalannya negara dan masa depan negara.

Perbedaan ideologi mengenai relasi agama dan negara tersebut telah berimplikasi pada polemik dan diskursus yang sudah muncul jauh sebelum kemerdekaan. Menjelang kemerdekaan, polemik ini semakin tajam dan nyata di ambang penentuan bentuk dan dasar negara yang akan dibentuk. Namun akhirnya, para pendiri bangsa berhasil mencapai suatu kesepakatan luhur yang mendamaikan pertentangan antar ideologi. Kesepakatan luhur itu disebut dengan Pancasila, sebuah sintesis dari ideologi-ideologi yang muncul dalam perdebatan perumusan UUD 1945.

Polemik relasi agama dan negara ternyata tidak sepenuhnya selesai dengan disepakatinya Pancasila sebagai dasar negara. Pasca kemerdekaan, polemik ini kembali muncul dalam beberapa kali pembahasan perumusan konstitusi. Namun pada akhirnya, polemik ini harus tunduk kembali pada kesepakatan mulia, Pancasila. Dengan begitu, implikasi dari polemik relasi agama dan negara sejauh ini berakhir pada kesepakatan mulia berupa Pancasila. Konsep negara berdasarkan Pancasila inilah yang sampai saat ini masih dianggap ampuh untuk mempersatukan bangsa Indonesia di dalam Negara Kesatuan Republik Indonesia.

Dalam hal ini, artikel ini ingin mengatakan bahwa implikasi ${ }^{58}$ paling mendasar-yang kemudian disebut implikasi pokok-dari

58 Dalam Kamus Besar Bahasa Indonesia, implikasi diartikan sebagai "keterlibatan atau keadaan terlibat" dan "yang termasuk atau tersimpul; yang disugestikan, tetapi tidak dinyatakan” (https://kbbi.kemdikbud.go.id/ entri/implikasi, diakses 10/11/2020). Merujuk definisi tersebut, maka implikasi polemik relasi agama dan negara pada pembentukan dan perubahan Konstitusi dalam artikel ini berarti adanya keterlibatan polemik tersebut dalam perdebatan di dalam pembentukan konstitusi, yang pada gilirannya melahirkan suatu akibat. 
polemik relasi agama dan negara dalam pembentukan dan perubahan Konstitusi UUD 1945 adalah tercapainya sebuah kesepakatan mulia yang dapat diterima semua kalangan, yaitu Pancasila. Sebagai sebuah kesepakatan, Pancasila dapat dikatakan merupakan kontrak sosial. ${ }^{59}$ Perlu pula dicatat, kesepakatan tersebut tidak hanya terjadi sekali melainkan berulang kali, sehingga menjadi kokoh dan dapat dikatakan telah teruji oleh zaman dan generasi hingga sejauh ini. Polemik yang terjadi telah mampu menurunkan tensi kepentingan dari semua pihak, dan menerima Pancasila sebagai landasan negara, sekaligus menjadikan Indonesia memiliki konsep negara yang khas dari negara-negara lainnya di dunia. Proses, dinamika, serta diskursus dalam polemik relasi agama dan negara telah berimplikasi pada lahirnya suatu sintesis konsep negara dari tawaran konsep-konsep negara yang ada menjelang kemerdekaan.

Selain dari implikasi pokok tersebut, masih ada sejumlah implikasi turunan-yang dapat disebut dengan implikasi cabang atau turunannya. Setidaknya ada lima implikasi cabang yang diidentifikasi dalam artikel ini, yaitu, pertama, Indonesia adalah negara yang berketuhanan dan mengakui eksistensi agama. Hal ini tercermin dari sila pertama Pancasila: Ketuhanan Yang Maha Esa. Namun begitu, Indonesia tidak menyatakan suatu agama tertentu sebagai agama resmi atau agama yang menjadi landasan negara. Hal ini berdampak pada konsep negara Indonesia yang tidak dapat disebut sebagai negara sekuler sekaligus secara bersamaan juga bukan negara teokrasi (negara agama). Indikator mengenai hal ini paling terlihat pada Sila

59 Pancasila sebagai kontrak sosial antara lain dikatakan oleh Onghokham, "Pancasila sebagai Kontrak Sosial”, http://perpustakaan.bappenas.go.id/ lontar $/$ file?file =digital $/$ blob $/$ F3683 $/$ Pancasila\%20sebagai\%20Kontrak\%20 Sosial.htm, diakses 10/11/2020. Uraian Idrus Ruslan menambahkan, karena mempersatukan, maka Pancasila selain kontrak sosial juga merupakan ligatur (pemersatu), yang dalam bahasa Agama disebut kalimah sawa' (Negara Madani: Aktualisasi Nilai-nilai Pancasila dalam Kehidupan Berbangsa dan Bernegara [Yogyakarta: SUKA-Press, 2015], hlm. 217). Sementara itu, Zacky Khairul Umam mengatakan, sebagai sebuah kesepakatan, Pancasila merupakan titik temu bagi kemajemukan, alias common denominator ("Desakralisasi Pancasila", Koran Tempo, 1/6/2006, https://koran.tempo. $\mathrm{co} / \mathrm{read} /$ opini / 72631/ desakralisasi-pancasila, diakses 10/11/2020. 
Pertama Pancasila, Ketuhanan Yang Maha Esa. Selain itu dalam isi Konstitusi, hal ini terlihat pada penegasan bahwa "Negara berdasar atas Ketuhanan Yang Maha Esa, yang dalam Konstitusi UUD 1945 terdapat pada pasal 29 ayat (1) dan Pasal 43 ayat (1) dalam UUDS $1950 .{ }^{60}$

Kedua, semua agama memiliki kedudukan yang sama di dalam negara Indonesia, baik dengan pemeluk yang mayoritas maupun minoritas, serta tidak mengenal adanya keistimewaan berdasarkan agama. Hal ini dibuktikan dengan setiap warga negara, apapun agamanya, secara konstitusional memiliki hak yang sama di dalam politik, bahkan hingga hak untuk mencalonkan diri sebagai presiden. Pada mulanya, dalam kesepakatan persiapan kemerdekaan, "Presiden ialah orang Indonesia asli yang beragama Islam”, lalu dalam Konstitusi yang dibentuk dan berlaku menjadi "Presiden ialah orang Indonesia asli", dan yang sekarang menjadi "warga negara Indonesia sejak kelahirannya dan tidak pernah menerima kewarganegaraan lain karena kehendaknya sendiri”. Indikator tentang ini bisa dilihat pada Pasal 6 ayat (1) UUD 1945, Pasal 69 ayat (3) Konstitusi RIS, dan Pasal 45 ayat (5) UUDS $1950 .^{61}$

Ketiga, negara memberikan jaminan perlindungan hak warga negara untuk memeluk agama dan menjalankan ajaran agamanya tersebut. Negara bahkan hadir untuk memfasilitasi umat beragama untuk dapat menunaikan ajaran agamanya secara aman, damai dan tenang, juga dalam pendirian rumah ibadah. Indikatornya dapat dilihat pada Pasal 29 ayat (2) dan Pasal 28E ayat (1) UUD 1945; Pasal 18, Pasal 39 ayat (2), dan Pasal 41 Konstitusi RIS; serta Pasal 18 dan Pasal 43 ayat (2), (3) dan (4) UUDS 1950.

60 Dalam satu Konstitusi lagi yang pernah berlaku, yaitu Konstitusi RIS, tidak terdapat ketentuan tentang negara berdasar atas Ketuhanan Yang Maha Esa di dalam isi atau batang tubuhnya, kecuali pada bagian "Mukadimah", dengan teks “.... berdasarkan pengakuan Ketuhanan Yang Maha Esa”.

61 Presiden tidaklah disebut harus orang Indonesia asli sebenarnya sudah terlihat dalam dalam Konstitusi RIS. Bahkan, Konstitusi RIS juga tidak menyebutkan warga negara Indonesia, melainkan "Presiden harus orang Indonesia yang telah berusia 30 tahun”. Dalam UUDS 1950, warga negara ini disebut secara tegas, “...harus warga-negara Indonesia yang telah berusia 30 tahun". 
Keempat, nilai-nilai agama menjadi salah satu pertimbangan yang dipakai untuk membatasi kebebasan dalam menjalankan hak asasi. Dengan begitu tidak ada kebebasan mutlak dalam menjalankan hak asasi. Indikator tentang ini terutama pada Konstitusi UUD 1945 setelah mengalami serangkaian amandemen pada 1999-2002, yang memang memberi perhatian yang lebih pada persoalan hak asasi manusia. Pada Pasal 28J ayat (2) UUD 1945, nilai-nilai agama disebut sebagai bagian dari yang dipertimbangkan dalam pembatasan hak asasi.

Kelima, peningkatan aspek spiritual keagamaan menjadi basis serta tujuan dalam pengembangan pendidikan di Indonesia. Sesuai dengan amanat konstitusi, penyelenggaraan sistem pendidikan nasional agar mencapai pada peningkatan keimanan dan ketakwaan serta akhlak mulia. Indikatornya dapat dilihat dalam rumusan Pasal 31 ayat (3) UUD 1945, Pasal 18 Konstitusi RIS, dan Pasal 41 UUDS 1950.

Itulah implikasi pokok beserta implikasi cabang atau turunan dari adanya polemik relasi agama dan negara dalam pembentukan dan perubahan Konstitusi UUD 1945. Kelima implikasi cabang yang disebutkan di atas berkorelasi langsung dan eksplisit di dalam batang tubuh UUD 1945. Sedangkan implikasi lain yang tidak disebutkan secara eksplisit di dalam UUD 1945 bisa menjadi bahan kajian selanjutnya.

Akan tetapi perlu juga menjadi catatan, bahwa melihat perjalanan polemik relasi agama dan negara dalam setiap perumusan konstitusi Indonesia, maka tidak menutup kemungkinan polemik yang sama akan muncul kembali di kemudian hari. ${ }^{62}$ Terlebih ketika amandemen UUD 1945 di era reformasi, keputusan akhir dalam Sidang Tahunan MPR-RI mengenai perdebatan soal Pasal 29 hanya menyimpulkan bahwa permasalahan tersebut belum sempat dibahas dalam Rapat Pleno Komisi A Majelis. Diskursus yang demikian itu,

62 Pan Mohamad Faiz, Islam dan Persaingan Ideologi di Parlemen (Studi Kasus: Pro Kontra Pemasukan "Tujuh Kata" Piagam Jakarta ke dalam Konstitusi pada Masa Reformasi), dalam Jurnal Hukum dan Pembangunan, 35, 2 (2005), hlm. 250. 
jika pun berulang, akan menguji tentang keampuhan dan kesaktian kesepakatan luhur bernama Pancasila. Namun demikian, juga diharapkan, agar polemik yang demikian itu tidak melupakan latar belakang historis sejauh ini.

\section{F. Kesimpulan}

Artikel ini menyimpulkan, pertama, polemik yang terjadi di Indonesia mengenai relasi antara agama dan negara sudah lama terjadi bahkan jauh sebelum kemerdekaan. Polemik ini terjadi antara golongan islamis dan golongan nasionalis. Golongan islamis menginginkan agar negara dan agama dapat melebur menjadi satu nafas, sehingga negara dapat berjalan sesuai agama dan ajaran agama dapat dilakukan oleh negara. Sedangkan golongan nasionalis menginginkan agar agama terpisah dari negara. Polemik ini terjadi sebelum, menjelang, dan setelah kemerdekaan Indonesia. Sebelum kemerdekaan, sudah terjadi polemik terbuka di media massa antara Soekarno dan Natsir. Menjelang kemerdekaan, golongan islamis dan nasionalis terlibat perdebatan sengit terkait dengan penentuan bentuk negara yang akan dirumuskan di dalam Undang-Undang Dasar 1945. Perdebatan sengit terulang kembali di dalam Konstituante, dan yang terakhir pada amandemen UUD 1945 di era reformasi.

Kedua, polemik agama dan negara ini berimplikasi pada lahirnya sebuah kesepakatan mulia berupa Pancasila sebagai dasar negara. Konsep Pancasila menjadi sintesis dari ideologi yang berseberangan mengenai relasi agama dan negara. Selain itu, dalam isi atau batang tubuh Konstitusi, polemik ini berimplikasi lebih lanjut pada pengakuan negara terhadap eksistensi agama-agama tertentu; perlakuan secara sama terhadap semua agama yang diakui; pemberian jaminan kebebasan penduduk untuk memeluk dan menjalankan ajaran agama; pengakuan dan penghormatan hak-hak asasi yang mempertimbangkan nilai-nilai agama; dan pengembangan pendidikan nasional yang berbasis dan berorientasi pada peningkatan aspek spiritual keagamaan. 


\section{Daftar Pustaka}

Abdillah, Masykur. Demokrasi di Persimpangan Makna Respons Intelektual Muslim Indonesia terhadap Konsep Demokrasi (19661993). Yogyakarta: Tiara Wacana, 1999.

Adam, Ronald. "Asal Mula Teori Animisme dan Masalahnya". https: / / crcs.ugm.ac.id/asal-mula-teori-animisme-dan-masalahnya/, 18/9/2019. Diakses 10/11/2020.

Anshari, Endang Saifuddin. Piagam Jakarta 22 Juni 1945 dan Sejarah Konsesus Nasional antara Nasionalis Islami dan Nasionalis Sekuler tentang Dasar Negara Republik Indonesia 1945-1959. Jakarta: Rajawali Press, 1986.

Asshiddiqie, Jimly. Konstitusi dan Konstitusionalisme Indonesia. Jakarta:

Konstitusi Press, 2005.

Aziz. "Islamisasi Nusantara Perspektif Naskah Sejarah Melayu". Thaqafiyyat, 16, 1 (2015): 53-76.

Boland, B.J. Pergumulan Islam di Indonesia 1945-1972. Terjemahan Saafroedin Bahar. Jakarta: Grafiti Press, 1985.

Bukhari, Marwan. "Menilai Kembali Negara Islam I”. Dalam Wacana Pemikiran Reformis Jilid 1, diedit oleh Ahmad Farouk Musa, 5358. Kuala Lumpur: Islamic Renaissance Front Berhad, 2012.

Faiz, Pan Mohamad. "Islam dan Persaingan Ideologi di Parlemen (Studi Kasus: Pro Kontra Pemasukan 'Tujuh Kata' Piagam Jakarta ke dalam Konstitusi pada Masa Reformasi)". Jurnal Hukum dan Pembangunan, 35, 2 (2005): 217-253. DOI: 10.21143/ jhp.vol35.no2.1464.

Idris, Irfan. Islam dan Konstitusionalisme: Kontribusi Islam dalam Penyusunan Undang-Undang Dasar Indonesia Modern. Yogyakarta: AntonyLib, 2009.

Indrati S, Maria Farida. Ilmu Perundang-Undangan: Jenis, Fungsi dan Muatan Materi. Yogyakarta: Penerbit Kanisius, 2007.

Jindan, Khalid Ibrahim. Teori Pemerintahan Islam Menurut Ibnu Taimiyah. Terjemahan Mufid. Jakarta: PT Rineka Cipta, 1994.

Liddle, R. William. "Tantangan Nasionalisme Bertuhan”. Harian Kompas, 20/09/2014. 
Lukito, Ratno. "Agama dan Negara di Indonesia: Kontestasi Teori". Bahan Diskusi Publik "Negara dan Agama", diselenggarakan Undang: Jurnal Hukum Fakultas Universitas Jambi, 14/11/2018. https: / / ujh.unja.ac.id/index.php/home/other/seminar/ diskusiNegara-Agama. Diakses 10/11/2020.

Maarif, Ahmad Syafii. Islam dan Masalah Kenegaraan: Studi tentang Percaturan dalam Konstituante. Jakarta: LP3ES, 1996.

Mahfud MD, Moh. Dasar dan Struktur Ketatanegaraan Indonesia. Yogyakarta: UII Press, 1993.

Republik Indonesia, Sekretariat Jenderal Majelis Permusyawaratan Rakyat. Risalah Perubahan Undang-Undang Dasar Negara Republik Indonesia Tahun 1945 (1999-2002) Tahun Sidang 2000 Buku Lima. Jakarta: Sekretariat Jenderal MPR-RI, 2008.

Musa, M. Yusuf. Politik dan Negara dalam Islam. Terjemahan M. Thalib. Surabaya: Al-Ikhlas, 1990.

Nastiti, Titi Surti. "Jejak-jejak Peradaban Hindu-Buddha di

Nusantara”. Kalpataru: Majalah Arkeologi, 23, 1 (2014): 35-49.

Nasution, Adnan Buyung. Aspirasi Pemerintahan Konstituasional di Indonesia: Studi Sosio-Legal atas Konstituante. Jakarta: Pustaka Utama Grafti, 1995.

Natsir, M. Agama dan Negara dalam Perspektif Islam. Jakarta: Penerbit Media Da’wah, tanpa tahun.

Onghokham. "Pancasila sebagai Kontrak Sosial”. http:// perpustakaan.bappenas.go.id / lontar / file?file=digital / blob / F3683 / Pancasila\%20sebagai\%20Kontrak\%20Sosial.htm. Diakses 10/11/2020.

Qodir, Zuly. Agama dalam Bayang-Bayang Kekuasaan. Yogyakarta: Interfidei, 2001.

Republik Indonesia, Mahkamah Konstitusi. Naskah Komprehensif Perubahan Undang-Undang Dasar Negara Republik Indonesia Tahun 1945, Buku VIII: Warga Negara dan Penduduk, Hak Asasi Manusia dan Agama. Jakarta: Sekretariat Jenderal dan Kepaniteraan Mahkamah Konstitusi, edisi revisi, 2010.

Ruslan, Idrus. Negara Madani: Aktualisasi Nilai-nilai Pancasila dalam Kehidupan Berbangsa dan Bernegara. Yogyakarta: SUKA-Press, 
2015.

Sadzali, Ahmad. Relasi Agama dan Negara: Teokrasi-Sekular-Tamyiz. Yogyakarta: Pusat Studi Hukum Islam Fakultas Hukum UII, 2018.

Saidi, Anas. "Relasi Pancasila, Agama dan Kebudayaan: Sebuah Refleksi”. Jurnal Masyarakat dan Budaya, 11, 1 (2009): 25-50. DOI: 10.14203/jmb.v11i1.233.

Simorangkir, J.C.T. Penetapan UUD: Dilihat dari Segi Ilmu Hukum Tata Negara Indonesia. Jakarta: PT. Gunung Agung, 1984.

Smith, Donald Eugene. Agama dan Modernisasi Politik: Suatu Kajian Analitis. Jakarta: Penerbit CV. Rajawali, 1985.

Soekarno. Di Bawah Bendera Revolusi. Jakarta: Panitian Penerbitan Di Bawah Bendera Revolusi, 1964.

Syafi'ie, M. "Pemikiran Organisasi Islam tentang Penerapan Hukum Pidana Islam: Tinjauan Hukum Hak Asasi Manusia”. Undang: Jurnal Hukum, 2, 2 (2019): 225-264. DOI: 10.22437/ujh.2.2.225264.

Taimiyah, Ibnu. Siyasah Syar'iyah: Etika Politik Islam. Terjemahan Rofi’ Munawwar. Surabaya: Risalah Gusti, 2005.

Umam, Zacky Khairul. "Desakralisasi Pancasila". Koran Tempo, 1/6/2006. https://koran.tempo.co/read/opini/72631/desakralisasi-pancasila. Diakses 10/11/2020.

Yamin, Muhammad. Naskah Persiapan Undang-Undang Dasar 1945, Jilid 1. Jakarta: tanpa penerbit, cetakan kedua, 1971. 